\title{
First record of Phoma selaginellicola on Selaginella kraussiana (African clubmoss): an invasive plant species in New Zealand
}

\section{McClymont $\mathrm{M}^{1}$, Waipara $\mathrm{N}^{2}$, Nessia $\mathrm{H}^{\mathbf{1}}$ and Blanchon $\mathrm{DJ}^{\mathbf{1}^{*}}$}

${ }^{1}$ Biodiversity and Animal Welfare Research Group, Department of Natural Sciences, Unitec Institute of Technology, Private Bag 92025, Auckland, New Zealand.

${ }^{2}$ Auckland Council, Private Bag 92300, Auckland, New Zealand.

McClymont M, Waipara N, Nessia H, Blanchon DJ 2013 - First record of Phoma selaginellicola on Selaginella kraussiana (African clubmoss): an invasive plant species in New Zealand. Plant Pathology \& Quarantine 3(2), 140-143, doi 10.5943/ppq/3/2/3

Phoma selaginellicola was detected on wild invasive plants of Selaginella kraussiana (African club moss). Identification was made based on colony characteristics, pycnidial and conidial morphology and comparison of ITS DNA sequences. This is the first record of the species for New Zealand and a new host species.

Key words - biological control - invasive plants - new host record - Phoma - Selaginella

\section{Article Information}

Received 18 July 2013

Accepted 12 September 2013

Published online 30 September 2013

*Corresponding author: Dan Blanchon - e-mail - dblanchon@unitec.ac.nz

\section{Introduction}

Phoma Sacc. is a complex, asexual fungal genus with a wide geographical range, more than 2,000 described infrageneric taxa (Montel et al. 1991) and a limited range of useful morphological characters to distinguish species. Species are found in numerous ecological niches, including as opportunistic or primary plant pathogens, saprobic soil or water organisms, or as parasites of other fungi, lichens, insects and vertebrates (Aveskamp et al. 2010). Recent reviews of the genus (e.g. Aveskamp et al. 2010) using molecular data have found Phoma to be polyphyletic.

Several species of Phoma have been reported for New Zealand, including $P$. commelinicola (E. Young) Gruyter on Tradescantia sp., $P$. digitalis Boerema on Digitalis, P. fallens Sacc. on Olea europaea L.,
P. haematocycla (Berk.) Aa \& Boerema on Phormium tenax J.R. Forst. \& G. Forst., P. paspali P.R. Johnst. on Paspalum dilatatum Poir. and Lolium perenne L., P. plurivora P.R. Johnst. on Setaria sp., P. pratorum P.R. Johnst. $\&$ Boerema on Lolium perenne and $P$. rhei (Ellis \& Everh.) Aa \& Boerema on Rheum rhaponticum L. (Aveskamp et al. 2010).

During a study investigating the impacts of the invasive ground cover Selaginella kraussiana (Kunze) A. Braun (African club moss) on native plants in New Zealand, areas of yellowing and wilting foliage were noted. Several Phoma-like fungi were isolated from shoots and cones. These isolates were associated with general dieback of plants, and necrotic browning of stems and strobili (cones) in wild plants of Selaginella kraussiana. Further investigation resulted in a 
positive identification of $P$. selaginellicola Gruyter, Noordel. \& Boerema, a new record for New Zealand.

\section{Methods}

A survey of Selaginella kraussiana patches was carried out in August 2011 in Spragg Bush, a 21 ha remnant of warmtemperate kauri/podocarp forest in the Waitakere Ranges (36 $\left.54^{\prime} \mathrm{S}, 174^{\circ} 32^{\prime} \mathrm{E}\right)$ in the Auckland region of New Zealand. Areas of damage were recorded and marked for further investigation. Samples of leaves, stems and strobili were taken from these areas of dieback, and surface sterilised with $0.5 \%$ sodium hypochlorite. Interior tissues in the zone between healthy and damaged plant tissue were dissected out in a laminar flow cabinet and placed onto plates of potato dextrose agar (PDA) amended with chloramphenicol. A range of fungal cultures developed, including isolates of Fusarium, Pestalotiopsis, Cladosporium and Phoma. The most commonly occuring isolates were morphologically identified as isolates of Phoma, and these were investigated further. Colony morphology and growth rate was recorded. Sections of pycnidia were made to examine wall morphology and conidia. A culture has been deposited in the International Collection of Micro-organisms from Plants (ICMP19751).

To confirm identification, the ribosomal DNA internal transcribed spacer region (ITS) was amplified and sequenced using primers ITS1f (Gardes \& Bruns 1993) and ITS4 (White et al. 1990). The sequence from the New Zealand isolate has been deposited in GenBank as accession KFO38323.

Pathogenicity testing was carried out on surface sterilised cutting-grown plants of Selaginella kraussiana. Three damaged and three undamaged plants were inoculated with agar plugs containing the fungal isolate. Damage was inflicted using a sterile needle, piercing six wounds into the stem and one wound into six leaves of each plant being damaged. After inoculation, individual plants were maintained at high humidity inside ziplock plastic bags and grown in a culture room at $21^{\circ} \mathrm{C}$. Plants were examined for signs of symptoms at weekly intervals for 3 weeks.

\section{Results}

After 5 days growth on PDA amended with chloramphenicol, the isolate colonies reached 29-37 $\mathrm{mm}$ in diameter. The culture on PDA matched the description for Phoma selaginellicola (de Gruyter et al. 1993), producing an olivaceous grey to buff colony with a fine velvety olivaceous grey aerial mycelium and grey concentric zones (Fig. 1).

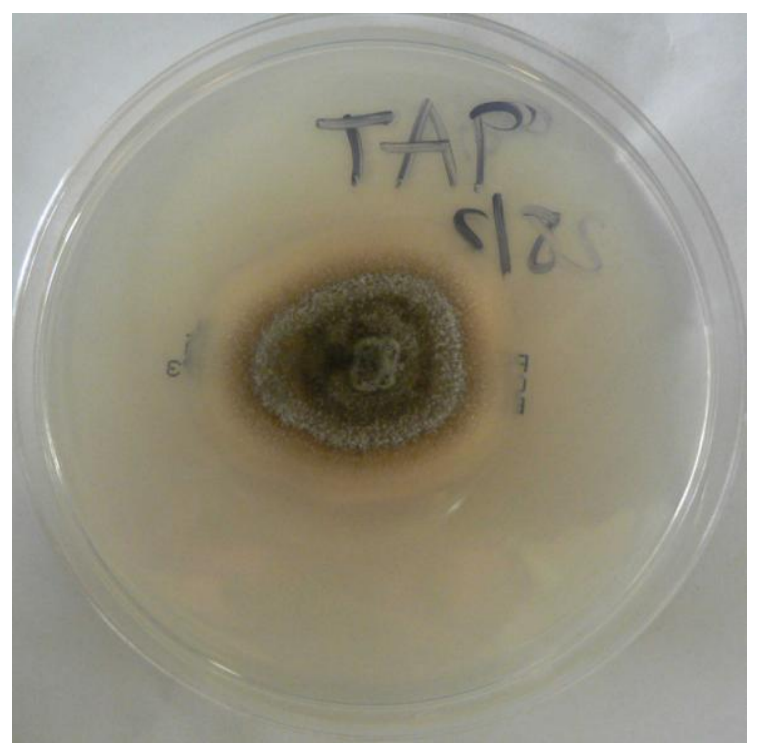

Fig. 1 - Phoma selaginellicola colony after 5 days growth on PDA with chloramphenicol.

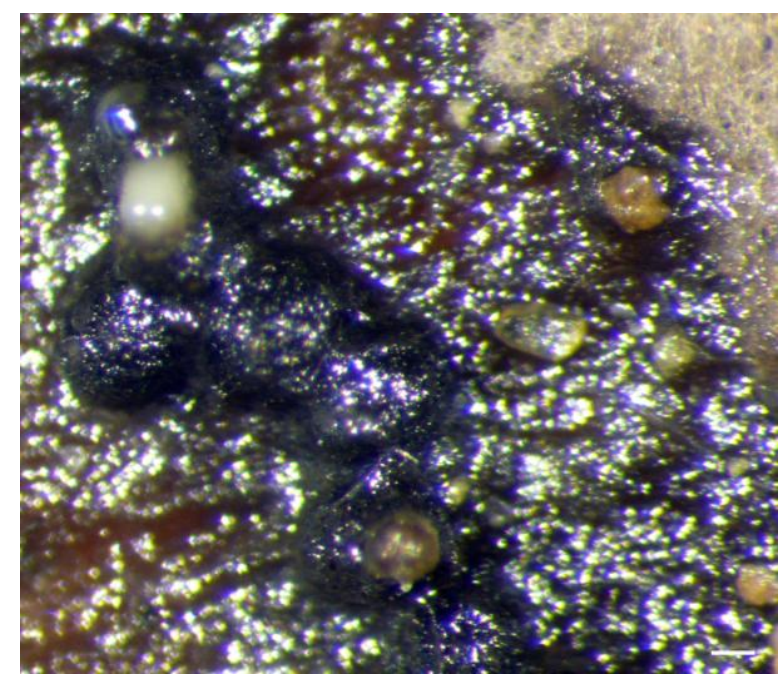

Fig. 2 - Pycnidia of Phoma selaginellicola. $\mathrm{Bar}=100 \mu \mathrm{m}$.

The reverse was brown-grey to black and no crystals were seen. Pycnidia were abundant, forming mainly on the surface of the agar, 145-395 $\mu \mathrm{m}$ in diameter, solitary to occasionally in clusters of $2-3$, with one 
usually non-papillate ostiole (Fig. 2), citrine to honey in colour when young, black when older. Pycnidial walls made up of 3-6 layers of cells, outer layers becoming pigmented brown to black on maturity (Fig. 3).

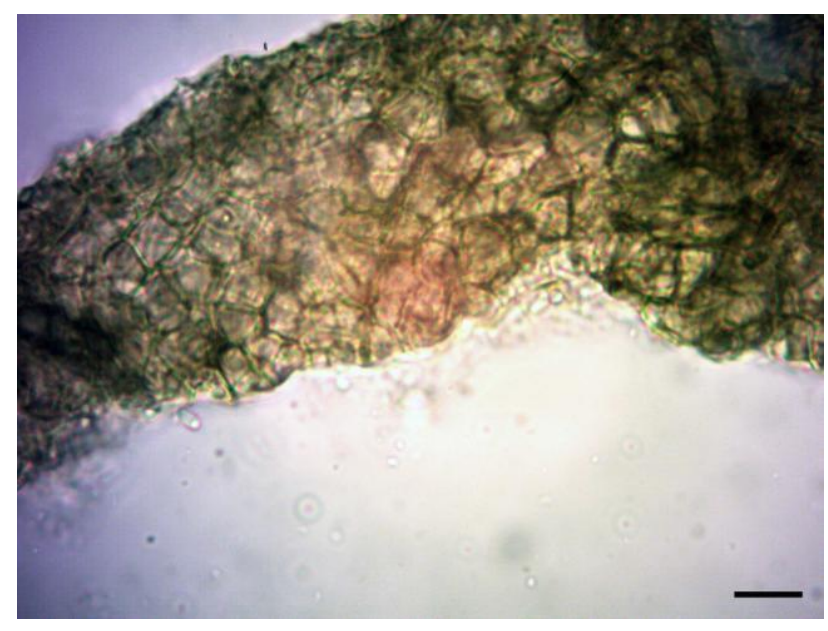

Fig. 3 - Section of the pycnidial wall of Phoma selaginellicola. Bar $=10 \mu \mathrm{m}$.

Conidial exudate was straw-coloured, visible through the aerial mycelium. Conidiogenous cells $4-6 \times 3.5-5 \mu \mathrm{m}$, globose to bottle shape. Conidia were ellipsoidal, occasionally curved, $3.5-4.5 \times 1.5-1.75 \mu \mathrm{m}$, average $3.9 \times 1.48 \mu \mathrm{m}$, with 2 or 3 guttules (Fig. 4). Chlamydospores were absent.

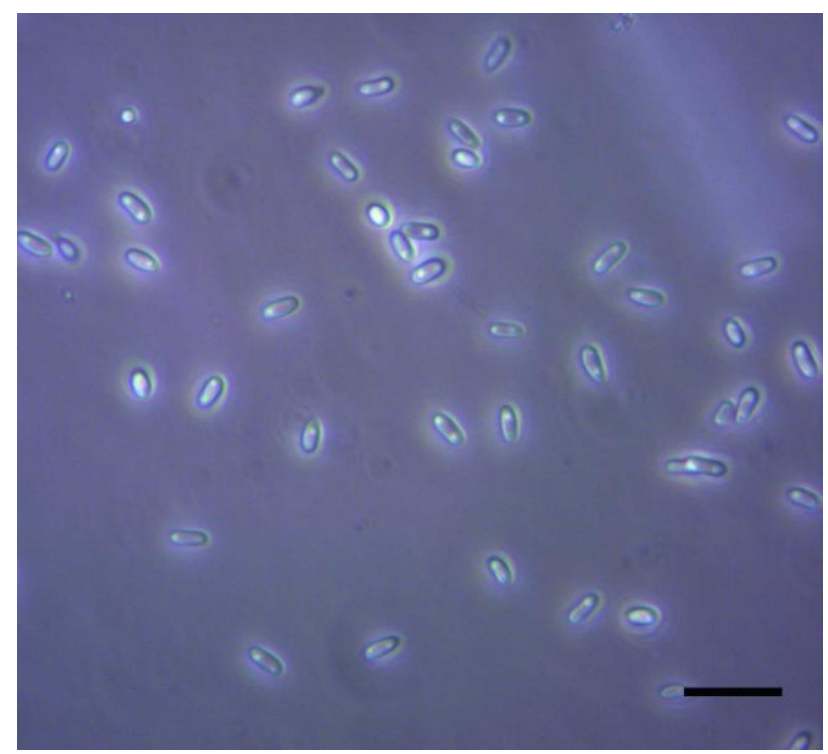

Fig. 4 - Conidia of Phoma selaginellicola. Bar $=10 \mu \mathrm{m}$.
The ITS sequence was $100 \%$ identical to a sequence identified as Phoma selaginellicola in GenBank (GU237762) by Aveskamp et al. (2010).

Within 14 days plants inoculated for pathogenicity testing exhibited yellowing of leaves and stems, while control plants remained green. After 3 weeks damaged and undamaged plants had $10-50 \%$ dieback of foliage (Fig. 5) and yellowing of cones. Samples were again taken, surface-sterilised and inoculated onto plates of PDA amended with chloramphenicol. Cultures morphologically identified as Phoma were consistently reisolated and DNA sequencing again generated ITS sequences identical to those of Phoma selaginellicola.

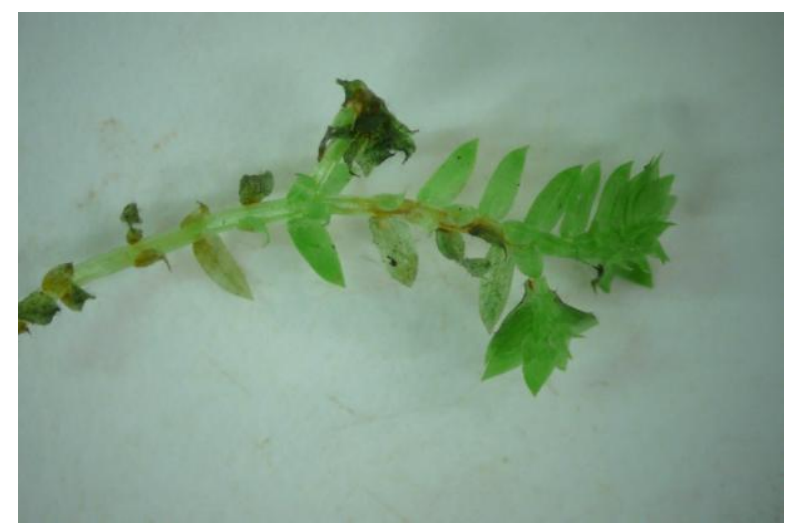

Fig. 5 - Shoot dieback of Selaginella kraussiana after in vitro inoculation with Phoma selaginellicola.

\section{Discussion}

This is the first report of Phoma selaginellicola from New Zealand, and from Selaginella kraussiana. Phoma selaginellicola has been previously reported from Italy and the Netherlands on $S$. helvetica, where it was associated with wilting leaves and leaf necroses (de Gruyter et al. 1993). One other species of Phoma, P. clematidina, has been recorded from an unknown species of Selaginella in the Netherlands (Woudenberg et al. 2009).

This report forms part of a study investigating possible pathogens of $S$. kraussiana. Selaginella kraussiana is an invasive ground cover which readily 
establishes in shady damp conditions (Barton 2005), and it is known to cause significant decreases in species richness and abundance of native plants (Barton et al. 2007). Barton (2005) reported that there had not been any pathogens recorded on Selaginella species in New Zealand, but did note that there were three fungal species which had been recorded as attacking Selaginella species elsewhere. Two smut fungi, Melaniella oreophila and $M$. selaginellae were found causing leaf and/or stem damage to Selaginella species in Zimbabwe, India and Java (Bauer et al. 1999), and a rust (Uredo vetus) was found in China (Hennen 1997). Previously, another fungal pathogen, Pestalotiopsis clavispora Atk. has been also shown to cause dieback in $S$. krausssiana (McClymont et al. 2013).

As part of our study, multiple fungal isolates were recovered from damaged tissue of Selaginella kraussiana, and it is likely that more fungal species will be identified in the future. Further research is continuing to determine if Phoma selaginellicola may be of use in the control of Selaginella kraussiana.

\section{Acknowledgements}

The authors would like to thank Mary Yan, Odette Rizk and Felicity Bowden for technical support and Auckland Council for funding this project.

\section{References}

Aveskamp MM, Gruyter J de, Woudenberg JHC, Verkley GJM, Crous PW 2010 Highlights of the Didymellaceae: a polyphasic approach to characterise Phoma and related pleosporalean genera. Studies in Mycology 65, 1-60.

Barton J 2005 - Prospects for biological control of African club moss (Selaginella kraussiana: Selaginellaceae). Landcare Research Contract Report: LC0405/066, Landcare, Lincoln, 24 pp.

Barton J, Fowler SV, Gianotti AF, Winks CJ, de Beurs M, Arnold GC, Forrester G
2007 - Successful biological control of mist flower (Ageratina riparia) in New Zealand: agent establishment, impacts and benefits to the native flora. Biological Control 40, 370-385.

Bauer R, Vanky K, Begerow D, Oberwinkler F 1999 - Ustilaginomycetes on Selaginella. Mycologia 91, 475-484.

Gardes M, Bruns TD 1993 - ITS primers with enhanced specificity for basidiomycetes - application to the identification of mycorrhizae and rusts. Molecular Ecology 2, 113-118.

Gruyter J de, Noordeloos ME, Boerema GH 1993 - Contributions towards a monograph of Phoma (Coelomycetes) 1.2. Section Phoma: additional taxa with very small conidia and taxa with conidia up to $7 \mu \mathrm{m}$ long. Persoonia $15,369-400$.

Hennen JF 1997 - Uredo vetus sp. nov., the first record of a rust on Selaginella, and the use of the name Uredo. Mycologia 89, 801-803.

McClymont, M, Nessia H, Waipara N, Blanchon DJ 2013 - First report of Pestalotiopsis clavispora from Selaginella kraussiana (African club moss): an invasive plant species in New Zealand. Australasian Plant Disease Notes. Online.

Montel E, Bridge PD, Sutton BC 1991 - An integrated approach to Phoma systematics. Mycopathologia 115, 89103.

White TJ, Bruns T, Lee S, Taylor JW 1990 Amplification and direct sequencing of fungal ribosomal RNA genes for phylogenetics. In: PCR Protocols: A Guide to Methods and Applications, (eds. Innis MA, Gelfand DH, Sninsky JJ, White TJ). Academic Press, New York, pp. 315-322.

Woudenberg JHC, Aveskamp MM, de Gruyter J, Spiers AG, Crous PW 2009 - Multiple Didymella teleomorphs are linked to the Phoma clematidina morphotype. Persoonia 22, 56-62. 